\title{
A Brief Review of the Pharmacology of Amitriptyline and Clinical Outcomes in Treating Fibromyalgia
}

\section{Kim Lawson}

Department of Biosciences and Chemistry, Biomolecular Sciences Research Centre, Sheffield Hallam University, Sheffield S1 1WB, UK; k.lawson@shu.ac.uk; Tel.: +44-(0)114-225-3057

Academic Editor: Shaker A. Mousa

Received: 12 March 2017; Accepted: 13 May 2017; Published: 17 May 2017

\begin{abstract}
Fibromyalgia is a complex chronic condition characterized by pain, physical fatigue, sleep disorder and cognitive impairment. Evidence-based guidelines recommend antidepressants as treatments of fibromyalgia where tricyclics are often considered to have the greatest efficacy, with amitriptyline often being a first-line treatment. Amitriptyline evokes a preferential reduction in pain and fatigue of fibromyalgia, and in the Fibromyalgia Impact Questionnaire (FIQ) score, which is a quality of life assessment. The multimodal profile of the mechanisms of action of amitriptyline include monoamine reuptake inhibition, receptor modulation and ion channel modulation. Several of the actions of amitriptyline on multiple nociceptive and sensory processes at central and peripheral locations have the potential to act cumulatively to suppress the characteristic symptoms of fibromyalgia. Greater understanding of the role of these mechanisms of action of amitriptyline could provide further clues to the pathophysiology of fibromyalgia and to a preferable pharmacological profile for future drug development.
\end{abstract}

Keywords: fibromyalgia; amitriptyline; monoamine transporters; pain; fatigue; Fibromyalgia Impact Questionnaire

\section{Introduction}

Fibromyalgia is a complex chronic condition characterized by widespread pain, physical fatigue, non-restorative sleep and cognitive impairment [1,2]. A high incidence of co-morbidities, such as depression, irritable bowel syndrome, headache and temporomandibular joint dysfunction, with variable intensity are reported [1,2]. The worldwide prevalence of fibromyalgia, based on application of the American College of Rheumatology (ACR) 1990 criteria, has been reported to range from $0.4 \%$ to $8 \%$ of the population, with the condition being more common in females [3]. Fibromyalgia is therefore a major social and financial burden for patients and healthcare systems warranting effective and safe treatment options. Amplified responses of the central nervous system (CNS) to peripheral sensory input leading to enhanced neuronal excitability and central sensitization have been reported to be associated with hyperalgesia and allodynia, which are symptoms characteristic of fibromyalgia [1]. Thus, pharmacological treatments of fibromyalgia are usually focused on lowering pronociceptive excitatory neurotransmission and/or increasing antinociceptive neurotransmission in the CNS [2].

The evidence-based guidelines of the European League Against Rheumatism (EULAR) and the Association of Medical Scientific Societies in Germany (AWMF) recommend antidepressants, such as amitriptyline, duloxetine and milnacipran, as pharmacological therapies for fibromyalgia [4-6]. Although antidepressants are commonly used in the treatment of chronic pain, the efficacy varies depending on the type and mechanism of action of the drug and the specific condition being treated [7]. Antidepressants act on noradrenergic and serotonergic neurons, which are implicated in the mediation of endogenous pain inhibitory mechanisms and associated with several aspects of the pathophysiology 
of fibromyalgia $[1,8]$. Descending serotonergic-noradrenergic and opioidergic efferent pathways, which form the diffuse noxious inhibitory control (DNIC), are activated in healthy subjects by the application of intense painful stimuli leading to downregulation of the pain signal. In patients with fibromyalgia, the DNIC has been reported to be reduced or absent [9]. Consistent with decreased endogenous serotonergic and noradrenergic activity and a reduced DNIC in patients with fibromyalgia is an altered biochemistry of serotonin and noradrenaline. Lower levels of main metabolites of serotonin and noradrenaline, 5-hydroxyindoleacetic acid (5-HIAA) and 3-methoxy-4-hydroxyphenethylene glycol (MHPG) respectively, in cerebrospinal fluid and of L-tryptophan and serotonin in blood are observed in patients with fibromyalgia compared to healthy controls $[1,8]$.

This review will focus on the pharmacology of amitriptyline that could be responsible for the benefits observed in the treatment of fibromyalgia.

\section{Pharmacology of Antidepressants and Fibromyalgia}

Serotonin reuptake transporters (SERT) and noradrenaline reuptake transporters (NET) are the main targets of antidepressants, such as tricyclic antidepressants (TCAs, e.g., amitriptyline), selective serotonin reuptake inhibitors (SSRIs, e.g., fluoxetine), serotonin and noradrenaline reuptake inhibitors (SNRIs, e.g., duloxetine and milnacipran) and selective noradrenaline reuptake inhibitors (NRIs, e.g., reboxetine). The affinities for monoamine reuptake transporters and selected neurotransmitter receptors of antidepressant drugs tested as treatments of fibromyalgia are summarized in Table 1 [10-21]. These antidepressants, through pharmacological actions on monoamine reuptake transporters, can facilitate the endogenous pain control system at neuroanatomical structures such as the locus coeruleus nucleus, the dorsal and magnus nuclei in the raphe, and the dorsal horn of the spinal cord [22]. A pathway from the midbrain periaqueductal gray (PAG) through the ventromedial medulla (VMM) to the dorsal horn constitutes a putative endogenous nociceptive modulatory system [23]. Evidence supports the PAG and VMM having multiple and coordinated effector functions that are not limited to nociceptive modulation but may involve homeostatic functions such as sleep-awake cycle, micturition and blood pressure [23]. A reciprocal feedback exists between the raphe nuclei and the suprachiasmatic nuclei, contributing to circadian rhythms and alteration of serotonin levels controlling sleep-awake states [24]. The locus coeruleus is a principal area for the synthesis of noradrenaline in the brain which, in addition to involvement in pain and stressor responses, mediates arousal of the sleep-awake cycle [25]. Consequently, many of the sympathetic effects during stress are mediated by the locus coeruleus increasing noradrenaline secretion and the raised noradrenaline levels alter, via a multimodal process, cognitive function through the prefrontal cortex $[25,26]$. Thereby, modulation of serotonin and noradrenaline levels, particularly within the descending processes, by the action of antidepressants on the monoamine reuptake transporters, has the potential of changing, in addition to pain, many of the characteristic symptoms of fibromyalgia. The involvement of serotonin and noradrenaline levels in the efficacy of antidepressants in fibromyalgia identifies 5-hydroxytryptamine (5-HT) and adrenergic receptors as playing a significant role in antinociceptive properties. Affinity for and/or efficacy at 5-HT and adrenergic receptors exhibited by antidepressants could influence the pain reducing profile but also result in unwanted effects $[27,28]$. Although action at muscarinic and histamine receptors of antidepressants has been related to the adverse cardiotoxicity and gastrointestinal disturbance, and sedative properties respectively, antinociceptive effects may also be achieved by actions at these receptors $[27,28]$. The efficacy of antidepressant drugs tested as treatments of fibromyalgia on the characteristic symptoms and quality of life assessments are summarized in Table 2 [29-70]. 
Table 1. Summary of affinities of antidepressant drugs for monoamine reuptake transporters and neurotransmitter receptors. Data are presented as concentrations $(\mathrm{nM})$ representing binding to the protein (Ki value) or exhibiting $50 \%$ inhibition of the protein function $\left(\mathrm{IC}_{50}\right.$ ); where multiple values are available, a range of the published values is presented. For 5-hydroxytryptamine (5-HT) and histamine receptors, subtypes are indicated in parentheses after the data values. For receptor subtypes not stated, $\mathrm{IC}_{50}$ value was $>10,000 \mathrm{nM}$. NET is the noradrenaline reuptake transporter; SERT is the serotonin reuptake transporter; DAT is the dopamine reuptake transporter. $\mathrm{N} / \mathrm{A}=$ not available.

\begin{tabular}{|c|c|c|c|c|c|c|c|c|}
\hline \multirow{3}{*}{ Drug } & \multirow{2}{*}{ NET } & \multirow{2}{*}{ SERT } & \multirow{2}{*}{ DAT } & \multicolumn{4}{|c|}{ Receptors } & \multirow{3}{*}{ References } \\
\hline & & & & Adrenergic & Muscarinic & Histamine & 5-HT & \\
\hline & $\mathrm{Ki} / \mathrm{IC}_{50} \mathrm{nM}$ & $\mathrm{Ki} / \mathrm{IC}_{50} \mathrm{nM}$ & $\mathrm{Ki} / \mathrm{IC}_{50} \mathrm{nM}$ & $\mathrm{IC}_{50} \mathrm{nM}$ & $\mathrm{IC}_{50} \mathrm{nM}$ & $\mathrm{IC}_{50} \mathrm{nM}$ & $\mathrm{IC}_{50} \mathrm{nM}$ & \\
\hline Amitriptyline & $13.3-63$ & $3.13-67$ & $2580-7500$ & $24-690$ & $7.2-26$ & 1.1(H1), $1000(\mathrm{H} 3), 33.6(\mathrm{H} 4)$ & $450(1 \mathrm{~A}), 40(1 \mathrm{~B}), 4(2 \mathrm{~A}), 40(2 \mathrm{~B}), 6(2 \mathrm{C}), 89-103(6), 126-398(7)$ & {$[10-12]$} \\
\hline Citalopram & $4870->10,000$ & $1.13-19.0$ & $>10,000$ & $560-1211$ & 1430 & $180-286$ & $617-6000(2)$ & {$[10,13,14]$} \\
\hline Cyclobenzaprine & 126 & 251 & 7943 & $10-110$ & $8-30$ & $1-6$ & $20(2 \mathrm{~A}), 200(2 \mathrm{~B}), 62(2 \mathrm{C}), 40(6), 69(7)$ & [11] \\
\hline Duloxetine & $1.17-42$ & $0.07-13$ & $200-439$ & $8300-8600$ & 3000 & 2300 & $504(2 \mathrm{~A}), 419(6)$ & {$[10,15-19]$} \\
\hline Fluoxetine & 563-1021 & $1.0-10$ & 4180 & 3000 & $870-2700$ & 3250 & $200(2 \mathrm{~A}), 5000(2 \mathrm{~B}), 73(2 \mathrm{C})$ & {$[12,16,18,20]$} \\
\hline Milnacipran & $22-200$ & $8.4-151$ & $>100,000$ & $>10,000$ & $>10,000$ & $>10,000$ & $>10,000$ & {$[10,16,18,19]$} \\
\hline Nortriptyline & $1.49-8.3$ & $16.5-317$ & $1200-5000$ & $55-2030$ & $40-110$ & $15.1(\mathrm{H} 1)$ & $294(1 \mathrm{~A}), 5(2 \mathrm{~A}), 8.5(2 \mathrm{C}), 148(6)$ & {$[10,12]$} \\
\hline Paroxetine & $100-156$ & $0.34-2$ & 963 & 2741 & $72-340$ & $>10,000$ & $9034(2 \mathrm{C})$ & {$[12,14,16,20]$} \\
\hline Reboxetine & 3-13.4 & $242-274$ & $>10,000$ & $>10000$ & 6700 & 312 & $457(2 \mathrm{C})$ & {$[12,14,16]$} \\
\hline Sertraline & $715-925$ & $0.9-2.8$ & 315 & 188 & 427 & 6578 & $2298(2 \mathrm{C})$ & {$[18,20]$} \\
\hline TD-9855 & $2-4$ & $3-10$ & $160-200$ & N/A & N/A & N/A & N/A & [21] \\
\hline Trazodone & $>10,000$ & 367 & $>7000$ & $153-728$ & $>10,000$ & 220(H1), 3290(H2) & $118(1 \mathrm{~A}), 106(1 \mathrm{D}), 36(2 \mathrm{~A}), 78(2 \mathrm{~B}), 224(2 \mathrm{C}), 1780(7)$ & [12] \\
\hline Venlafaxine & $538-2483$ & $7.8-145$ & 3070-7647 & $>10,000$ & $>10,000$ & $>10,000$ & $2000(2), 2800(6)$ & {$[10,13,16-19$} \\
\hline
\end{tabular}


Table 2. Efficacy of antidepressant drugs in the treatment of fibromyalgia. Data are presented based on the effects of antidepressant drugs on the Fibromyalgia Impact Questionnaire (FIQ), Patient's Global Impression Assessment and primary symptoms. Changes in score ratings are presented on a 0 to 10 scale, except FIQ (0-100),

Hamilton Rating Scale for Depression (HDRS), Hamilton Anxiety Rating Scale (HAM-A; 0-56), Beck Depression Inventory (BDI; 0-63), Beck Anxiety Inventory (BAI; 0-63), and Montgomery-Åsberg Depression Rating Scale (MADRS; 0-60). The proportion (\%) of patient population gaining significant benefit for a domain, where available, is indicated by . MOS = Sleep Scale from the Medical Outcomes Study; VLD = very low dose.

\begin{tabular}{|c|c|c|c|c|c|c|c|c|}
\hline \multirow{2}{*}{ Drug } & \multirow{2}{*}{ Dose (mg/day) } & \multirow{2}{*}{ FIQ } & \multirow{2}{*}{ Patient's Global Assessment } & \multicolumn{4}{|c|}{ Symptoms } & \multirow[t]{2}{*}{ References } \\
\hline & & & & Pain & Fatigue & Sleep & Anxiety and Depression & \\
\hline Amitriptyline & $10-100$ & -13 to -19 & -0.5 to $-3.887 \%^{\#}$ & -0.4 to -5.3 & $\begin{array}{l}-2.2 \text { to } 3.5 \\
80-93 \%\end{array}$ & -1.1 to $-3.963-100 \% \#$ & $\begin{array}{l}\text { HDRS }-9.9 \text { to }-10.4 \text { BDI } \\
\quad-6.2 \text { to }-7.050 \%\end{array}$ & [29-41] \\
\hline Citalopram & $20-40$ & & $52.9 \% \#$ & -1.2 & & -0.59 & MADRS -4.0 & [42] \\
\hline $\begin{array}{l}\text { Cyclobenzaprine } \\
\text { (TNX102SL) }\end{array}$ & 10 VLD $1-4$ & & & -0.9 & No effect & Parameters improved $12.3-38.5 \%$ & Improved $24.1 \%$ & [43-47] \\
\hline Duloxetine & $30-120$ & -7.96 to -18.4 & -2.79 to -3.43 & -1.6 to -2.4 & -0.33 to -3.8 & -2.67 to -2.69 Caused insomnia & $\begin{array}{c}\text { BDI }-3.32 \text { to }-5.47 \text { HDRS } \\
-2.04 \text { to }-7.8\end{array}$ & {$[48-56]$} \\
\hline Esreboxetine & $4-10$ & -3.9 to -7.2 & $40-42.6 \%{ }^{\#}$ & -0.4 to -0.76 & -0.59 to -0.64 & Caused insomnia & & [57] \\
\hline Fluoxetine & $10-80$ & -10.9 to -11.5 & -1.77 & -2.3 to -2.4 & -1.6 & -0.86 & No effect & {$[32,58]$} \\
\hline Milnacipran & $30-200$ & -12.3 to -26 & $35-51 \% \#$ & -1.6 to -3.5 & -4.3 to -7.3 & No effect & BDI -2.1 to -4.9 & [59-63] \\
\hline Paroxetine & $12.5-62.5$ & -6.6 to -6.8 & $45-55 \%{ }^{\#}$ & -0.95 & & -4.6 to -4.9 & BDI -4.6 to -5.8 & {$[64,65]$} \\
\hline Sertraline & 50 & & $83 \% \#$ & -4.2 & & MOS Score -15 & & [66] \\
\hline TD-9855 & 20 & -16.2 & $48 \% \#$ & -1.4 & & Caused insomnia & & [67] \\
\hline Trazodone & $50-300$ & -9.6 to -13.4 & & -0.52 to -1.41 & -0.72 to -1.17 & -4.2 to -5.0 & $\begin{array}{c}\text { HDRS }-1.4 \text { to }-2.0 \\
\text { HAM-A }-1.5 \text { to }-2.4 \text { BDI } \\
-5.5 \text { to }-8.9\end{array}$ & [68] \\
\hline Venlafaxine & $75-300$ & -9.0 to -19.9 & $51 \% \#$ & -1.87 to -2.14 & $35 \%{ }^{\#}$ & & $\begin{array}{c}\text { HDRS }-3.6 \text { to }-4.65 \\
\text { HAM-A }-7.14 \text { to }-13.5 \\
\text { BAI }-8.5 \\
\text { BDI }-7.9\end{array}$ & {$[34,69]$} \\
\hline
\end{tabular}


The optimum analgesic action of antidepressants in the treatment of fibromyalgia, as with other chronic pain conditions, is usually achieved with a dose lower than that required to achieve mood enhancement indicative of intrinsic analgesic efficacy [22]. Although the analgesic response is distinct from the effects on mood as indicated by the variation in analgesic efficacy among the chemical classes, many of the antidepressants over the dose range used in the treatment of fibromyalgia also reduce anxiety and depression scores (Table 2). Antidepressants exhibit diverse pharmacological properties with individual agents (within a class) exhibiting such effect to variable degrees, and this may account for possible differing outcomes in the treatment of fibromyalgia.

\section{Pharmacology of Amitriptyline and Fibromyalgia}

Of the range of antidepressant classes (TCAs, SNRIs, SSRIs, NRIs), TCAs are often considered to have the greatest analgesic efficacy, with amitriptyline (10-50 mg/day) being recommended as a first-line treatment for fibromyalgia [4-6]. The use and acceptance of TCAs in patients with fibromyalgia will be enhanced by the adverse effects often reported for this class of drugs occurring less commonly and with less severity when used as analgesics than as antidepressants [22].

A preferential outcome in the reduction of pain and fatigue associated with fibromyalgia and in the Fibromyalgia Impact Questionnaire (FIQ) score, which reflects a quality of life assessment, was observed with amitriptyline (10-100 mg/day) compared to the majority of other antidepressants (Figure 1; Table 2). The efficacy of amitriptyline relative to other classes of antidepressants (e.g., SNRIs, SSRIs and NRIs) infers that modulation of monoamine reuptake mechanisms and additional pharmacological properties are required to control the symptoms of fibromyalgia.

Although amitriptyline evokes a relatively balanced inhibition of serotonin and noradrenaline reuptake, the main metabolite, nortriptyline, preferentially inhibits noradrenaline reuptake (Table 1) [70]. Thus, in a clinical setting, the net outcome of amitriptyline treatment will place an emphasis on inhibiting noradrenaline reuptake, which may be relevant to changes in the biology of patients with fibromyalgia. For example, an increased release of substance $\mathrm{P}$, a mediator of $C$ fibres which contributes to central sensitization, is expressed as hyperalgesia if noradrenergic neuronal activity or the levels of noradrenaline decrease [71]. In patients with fibromyalgia, substance $P$ levels are raised in the cerebrospinal fluid which could induce pain through the activation of neurokinin 1 receptors [8]. In addition to inhibiting presynaptic reuptake of noradrenaline and serotonin, amitriptyline has affinity for $\alpha$-adrenergic, histamine, muscarinic cholinergic, 5-HT, $\mathrm{N}$-methyl-D-aspartate (NMDA) and opioid receptors (Table 1) [12].

Although pain in patients with fibromyalgia is probably mediated by alternating activity levels in the CNS, associated with hyperexcitability, peripheral nociceptive generators enhancing the symptoms also play a role in the pathophysiology and need to be considered in the management of the condition [1,2,8]. A peripheral analgesic effect of antidepressants has been proposed [72]. Inhibition of the monoamine reuptake transporters, however, is unlikely to be the mechanism of action responsible for the analgesic properties of amitriptyline, because noradrenaline and serotonin enhance nociceptive transmission at a peripheral level. Thus, blockade of adrenoceptors and 5-HT receptors, and possibly of histamine and muscarinic receptors, as observed with amitriptyline but not SNRIs and SSRIs, is a more likely contributory analgesic mechanism of action at a peripheral level in patients with fibromyalgia [22]. Peripheral adenosine A1 receptors have also been proposed to be involved in systemically administered amitriptyline-induced antinociception [73]. Amitriptyline and other TCAs inhibit the neuronal uptake of adenosine which would lead to enhanced stimulation of adenosine receptors at both peripheral and CNS levels producing analgesia [28]. Interestingly, raised adenosine levels associated with D-ribose treatment have been reported to reduce symptoms in patients with fibromyalgia [74]. 


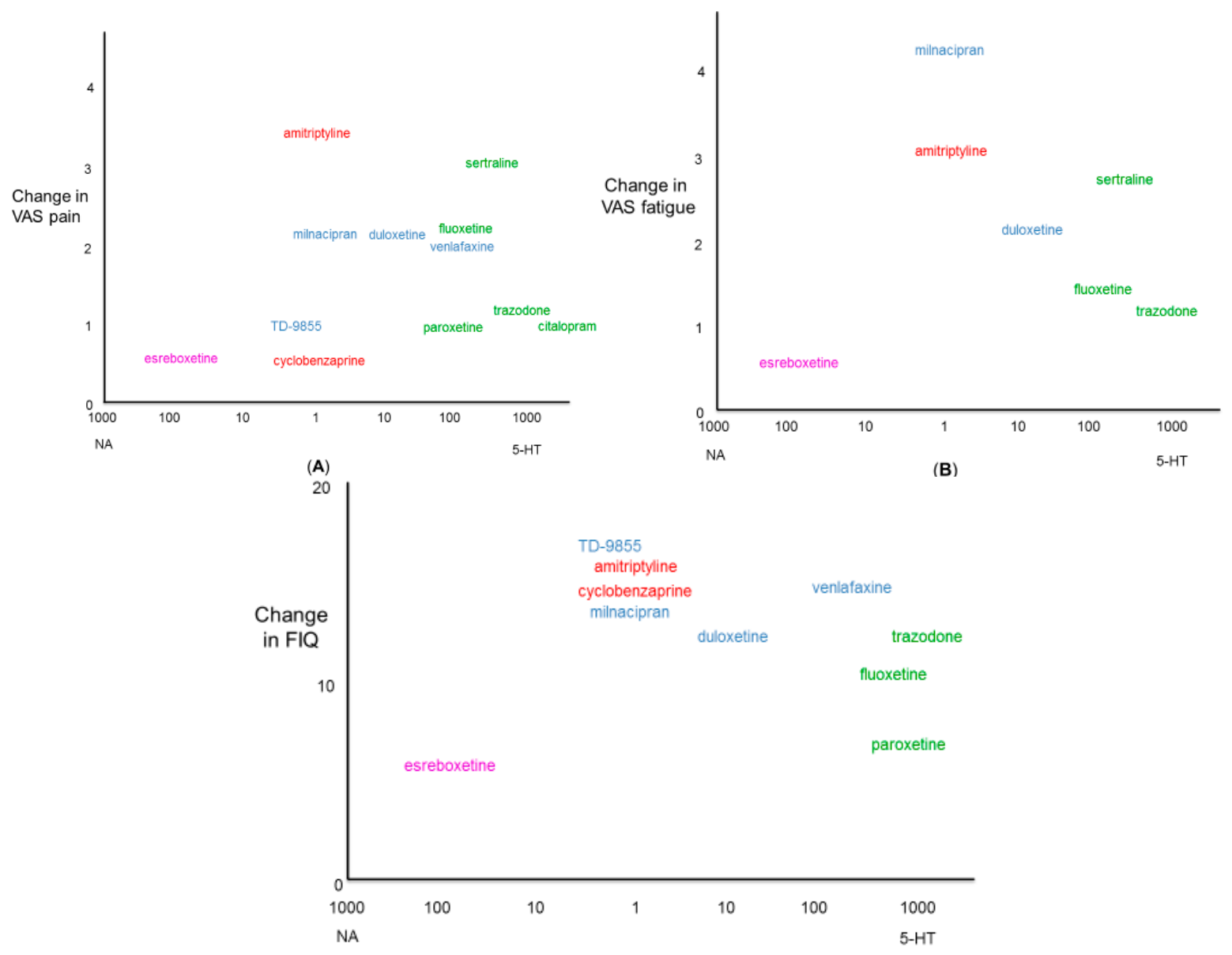

(C)

Figure 1. Schematic of monoamine transporter selectivity and efficacy of antidepressant drugs to reduce pain (A), fatigue (B) and Fibromyalgia Impact Questionnaire (FIQ) score (C) in patients with fibromyalgia. Selectivity ratios for the antidepressant drugs were determined from affinity and inhibitory properties for noradrenaline reuptake transporter (NET) and serotonin reuptake transporter (SERT) where NA indicates a selectivity for NET over SERT values and 5-HT indicates a selectivity for SERT over NET (see Table 1). Pain measurement (A) is presented as change on a 0-10 scale visual analogue scale (VAS); fatigue measurement (B) is presented as change on a 0-10 scale VAS; FIQ score (C) is presented as a change on a $0-100$ scale (see Table 2). TCAs are indicated in red, SNRIs in blue, SSRIs in green and NRIs in purple.

Although amitriptyline has been demonstrated to bind to opioid receptors and NMDA receptors, interaction with these receptors at therapeutic drug concentrations has been the subject of debate [70]. Antidepressants binding to the NMDA receptor reduce glutamate-induced intracellular calcium accumulations which would lead to suppression of cell excitation $[75,76]$. The neuronal hyperexcitability that is observed in fibromyalgia, causing both spontaneous and stimulus-evoked pain, may be a consequence of heightened sensitivity of the NMDA receptor-operated ion channels, which could have an impact on the concentrations of amitriptyline evoking a therapeutic effect [77]. The opioidergic system also appears to be involved in the mechanism of action of certain antidepressants that have antihyperalgesic action, such as TCAs, but not those with antinociceptive effects (e.g., duloxetine), which is an analgesic profile that would be relevant to the symptoms characteristic of fibromyalgia [78].

At therapeutic drug concentrations, amitriptyline also interacts with sodium, calcium and potassium channels. TCAs block open and inactivated states of sodium channels by binding to 
the local anaesthetic receptor, a property that may contribute to the analgesic efficacy in patients with fibromyalgia [79]. Although the action at potassium channels has been suggested to be involved in the adverse effects of amitriptyline (e.g., cardiac events), the role of interaction with specific calcium and potassium channel subtypes at therapeutic concentrations with the beneficial effects in humans needs further investigation. Central antinociception induced by amitriptyline has been reported to involve the opening of different subtypes of $\mathrm{K}^{+}$channels (voltage-gated $\mathrm{Kv1.1}, \mathrm{K}_{\mathrm{ATP}}$ and $\mathrm{Ca}^{2+}$-gated) which represent important intracellular effectors in the analgesic activity of TCAs [80]. Further, amitriptyline has an affinity for the Kv7 family of potassium channels, which are the targets of potential treatments of fibromyalgia [81,82].

Dopamine deficiency in the CNS has also been implicated in the pathophysiology of fibromyalgia, with a decrease in dopamine concentration leading to central pain sensitization [83]. There may also be a correlation between the decrease in dopamine levels and other symptoms of fibromyalgia such as fatigue, sleep disturbances and depression. This has raised interest in direct or indirect dopaminergic actions as a potential mechanism for the treatment of fibromyalgia. Although amitriptyline has been suggested to exhibit limited effects on the dopaminergic system, the combination of amitriptyline and fluoxetine as a treatment of fibromyalgia was suggested to offer a preferable serotonin/noradrenaline/dopamine uptake inhibition than what was provided by the individual drugs [32]. Sertraline and TD-9855 offer a reduction of the pain and fatigue levels, and they have a FIQ score similar to amitriptyline (Figure 1); however, they are more potent inhibitors of the dopamine reuptake transporter (Table 1). This additional property of sertraline and TD-9855 may enhance the symptom-relieving effects obtained with serotonergic and noradrenergic mechanisms of action. Bupropion has been reported to inhibit the dopamine reuptake transporters and NETs, but not the neuronal reuptake of serotonin [84]. A case study in a patient with fibromyalgia reported that bupropion improved pain scores and other fibromyalgia symptoms such as depression and cognitive function, over a two-month period [85]. Sibutramine, a serotonin/noradrenaline/dopamine reuptake inhibitor, has also been shown to reduce pain and fatigue, and increase overall functioning in patients with fibromyalgia [86]. Involvement of the dopamine system in the actions of amitriptyline as a treatment of fibromyalgia is worthy of further consideration.

A multimodal action of amitriptyline in fibromyalgia probably involves CNS and peripheral targets with contributory actions on receptors and ion channels in addition to monoamine reuptake inhibition.

\section{Conclusions}

Treatment of fibromyalgia remains a major unmet medical need and optimal translation of current research to the clinic has been limited. Nociceptive signalling involves a range of receptors, mediators, cells, and physiological and genetic changes supporting the need to target multiple events to evoke effective control of the symptoms of diverse patients with fibromyalgia. Consequently, drugs that act through diverse mechanisms and that are given as combination therapy are often standard for the treatment of fibromyalgia [4-6,87]. Several of the actions of amitriptyline have the potential to cumulatively interfere with, at least, the pain mechanism in fibromyalgia. Relative to other antidepressants (SNRIs, SSRIs, NRIs), TCAs could be more effective as analgesics because of their actions on multiple nociceptive and sensory targets at central and peripheral levels.

The heterogeneity of fibromyalgia has led to the proposal of the existence of subgroups of patients [88]; however, analgesic drug development is based on the mean responses of groups of patients with the same condition given the same drug and dose, with individual subjects or subgroups of the patient population given little consideration [89]. With such a heterogeneous condition, effectiveness is going to be dependent on multimodal pharmacology, as exhibited by amitriptyline. Understandably, involvement of a diverse pharmacology has the potential of increasing the incidence and profile of adverse effects which may lead many patients to discontinue use. Greater understanding of the role of the mechanisms of action of amitriptyline in the management of the symptoms of 
fibromyalgia requires further investigation to provide clues about the pathophysiology of the condition and to provide a preferable pharmacological profile for future drug development.

Acknowledgments: There were no funding sources for this review.

Conflicts of Interest: The author declares no conflict of interest.

\section{References}

1. Borchers, A.T.; Gershwin, M.E. Fibromyalgia: A critical and comprehensive review. Clin. Rev. Allergy Immunol. 2016, 49, 100-151. [CrossRef] [PubMed]

2. Lawson, K. Potential drug therapies for the treatment of fibromyalgia. Exp. Opin. Investig. Drugs 2016, 25, 1071-1081. [CrossRef] [PubMed]

3. Queiroz, L.P. Worldwide epidemiology of fibromyalgia. Curr. Pain Headache Rep. 2013, 17, 356. [CrossRef] [PubMed]

4. Macfarlane, G.J.; Kronisch, C.; Dean, L.E.; Atzeni, F.; Häuser, W.; Fluß, E.; Choy, E.; Kosek, E.; Amris, K.; Branco, J.; et al. EULAR revised recommendations for the management of fibromyalgia. Ann. Rheum. Dis. 2016. [CrossRef] [PubMed]

5. Häuser, W.; Arnold, B.; Eich, W.; Felde, E.; Flügge, C.; Henningsen, P.; Herrmann, M.; Köllner, V.; Kühn, E.; Nutzinger, D.; et al. Management of fibromyalgia syndrome-An interdisciplinary evidence-based guideline. Ger. Med. Sci. 2008, 6, 1-11.

6. Kia, S.; Choy, E. Update on treatment guideline in fibromyalgia syndrome with focus on pharmacology. Biomedicines 2017, 5, 20. [CrossRef]

7. Mika, J.; Zychowska, M.; Makuch, W.; Rojewska, E.; Przewlocka, B. Neuronal and immunological basis of action of antidepressants in chronic pain-Clinical and experimental studies. Pharmacol. Rep. 2013, 65, 1611-1621. [CrossRef]

8. Sluka, K.A.; Clauw, D.J. Neurobiology of fibromyalgia and chronic widespread pain. Neuroscience 2016, 338, 114-129. [CrossRef] [PubMed]

9. Julien, N.; Goffaux, P.; Arsenault, P.; Marchand, S. Widespread pain in fibromyalgia is related to a deficit of endogenous pain inhibition. Pain 2005, 114, 295-302. [CrossRef] [PubMed]

10. Vaishnavi, S.N.; Nemeroff, C.B.; Plott, S.J;; Rao, S.G.; Kranzler, J.; Owens, M.J. Milnacipran: A comparative analysis of human monoamine uptake and transporter binding affinity. Biol. Psychiatry 2004, 55, 320-322. [CrossRef] [PubMed]

11. Mestres, J.; Seifert, S.A.; Oprea, T.I. Linking pharmacology to clinical reports: Cyclobenzaprine and its possible association with serotonin syndrome. Clin. Pharmacol. Ther. 2011, 90, 662-665. [CrossRef] [PubMed]

12. Roth, B.L.; Driscol, J. PDSP Ki Database. In Psychoactive Drug Screening Program (PDSP); United States National Institute of Mental Health, University of North Carolina: Chapel Hill, NC, USA, 2011.

13. Koch, S.; Perry, K.W.; Nelson, D.L.; Conway, R.G.; Threlkeld, P.G.; Bymaster, F.P. R-fluoxetine increases extracellular DA, NE, as well as 5-HT in rat prefrontal cortex and hypothalamus: An in vivo microdialysis and receptor binding study. Neuropsychopharmacology 2002, 27, 949-959. [CrossRef]

14. Dekeyne, A.; Millan, M.J. Discriminative stimulus properties of the atypical antidepressant, mirtazapine, in rats: A pharmacological characterization. Psychopharmacology 2009, 203, 329-341. [CrossRef] [PubMed]

15. Murai, N.; Aoki, T.; Tamura, S.; Sekizawa, T.; Kakimoto, S.; Tsukamoto, M.; Oe, T.; Enomoto, R.; Hamakawa, N.; Matsuoka, N. AS1069562, the (+)-isomer of indeloxazine, exerts analgesic effects in a rat model of neuropathic pain with unique characteristics in spinal monoamine turnover. J. Pharmacol. Exp. Ther. 2014, 348, 372-382. [CrossRef] [PubMed]

16. Mahaney, P.E.; Vu, A.T.; McComas, C.C.; Zhang, P.; Nogle, L.M.; Watts, W.L.; Sarkahian, A.; Leventhal, L.; Sullivan, N.R.; Uveges, A.J.; et al. Synthesis and activity of a new class of dual acting norepinephrine and serotonin reuptake inhibitors: 3-(1H-indol-1-yl)-3-arylpropan-1-amines. Bioorg. Med. Chem. 2006, 14, 8455-8466. [CrossRef] [PubMed]

17. Bymaster, F.P.; Dreshfield-Ahmad, L.J; Threlkeld, P.G.; Shaw, J.L.; Thompson, L.; Nelson, D.L.; Hemrick-Luecke, S.K.; Wong, D.T. Comparative affinity of duloxetine and venlafaxine for serotonin and norepinephrine transporters in vitro and in vivo, human serotonin receptor subtypes, and other neuronal receptors. Neuropsychopharmacology 2001, 25, 871-880. [CrossRef] 
18. Koch, S.; Hemrick-Luecke, S.K.; Thompson, L.K.; Evans, D.C.; Threlkeld, P.G.; Nelson, D.L.; Perry, K.W.; Bymaster, F.P. Comparison of effects of dual transporter inhibitors on monoamine transporters and extracellular levels in rats. Neuropharmacology 2003, 45, 935-944. [CrossRef]

19. Marks, D.M.; Shah, M.J.; Patkar, A.A.; Masand, P.S.; Park, G.Y.; Pae, C.U. Serotonin-norepinephrine reuptake inhibitors for pain control: Premise and promise. Curr. Neuropharmacol. 2009, 7, 331-336. [CrossRef] [PubMed]

20. Owens, J.M.; Knight, D.L.; Nemeroff, C.B. Second generation SSRIs: Human monoamine transporter binding profile of escitalopram and R-fluoxetine. Encephale 2002, 28, 350-355. [CrossRef]

21. Smith, J.A.; Bourdet, D.L.; Daniels, O.T.; Ding, Y.S.; Gallezot, J.D.; Henry, S.; Kim, K.H.; Kshirsagar, S.; Martin, W.J.; Obedencio, G.P.; et al. Preclinical to clinical translation of CNS transporter occupancy of TD-9855, a novel norepinephrine and serotonin reuptake inhibitor. Int. J. Neuropsychopharmacol. 2014, 18, pyu027. [CrossRef] [PubMed]

22. Micó, J.A.; Ardid, D.; Berrocoso, E.; Eschalier, A. Antidepressants and pain. Trends Pharmacol. Sci. 2006, 27, 348-354. [CrossRef] [PubMed]

23. Mason, P. Deconstructing endogenous pain modulations. J. Neurophysiol. 2005, 94, 1659-1663. [CrossRef] [PubMed]

24. Deurveilher, S.; Kazue, S. Reciprocal connections between the suprachiasmatic nucleus and the midbrain raphe nuclei: A putative role in the circadian control of behavioral states. In Serotonin and Sleep: Molecular, Functional and Clinical Aspects; Monti, J.M., Pandi-Perumal, S.R., Jacobs, B.L., Nutt, D.J., Eds.; Birkhäuser: Basel, Switzerland, 2008; pp. 103-131.

25. Benarroch, E.E. The locus ceruleus norepinephrine system: Functional organization and potential clinical significance. Neurology 2009, 73, 1699-1704. [CrossRef] [PubMed]

26. Ramos, B.P.; Arnsten, A.F. Adrenergic pharmacology and cognition: Focus on the prefrontal cortex. Pharmacol. Ther. 2007, 113, 523-536. [CrossRef] [PubMed]

27. Nekovarova, T.; Yamamotova, A.; Vales, K.; Stuchlik, A.; Fricova, J.; Rokyta, R. Common mechanisms of pain and depression: Are antidepressants also analgesics? Front. Behav. Neurosci. 2014, 8, 99. [CrossRef] [PubMed]

28. Sawynok, J.; Esser, M.J.; Reid, A.R. Antidepressants as analgesics: An overview of central and peripheral mechanisms of action. J. Psychiatry Neurosci. 2001, 26, 21-29. [PubMed]

29. Carette, S.; Oakson, G.; Guimont, C.; Steriade, M. Sleep electroencephalography and the clinical response to amitriptyline in patients with fibromyalgia. Arthritis Rheum. 1995, 9, 1211-1217. [CrossRef]

30. Ginsberg, F.; Mancaux, A.; Joos, E.; Vanhove, P.; Famaey, J.P. A randomized placebo-controlled trial of sustained-release amitriptyline in primary fibromyalgia. J. Musculoskelet. Pain 1996, 4, 37-47. [CrossRef]

31. Goldenberg, D.; Felson, D.; Dinerman, H. A randomized, controlled trial of amitriptyline and naproxen in the treatment of patients with fibromyalgia. Arthritis Rheum. 1986, 29, 1371-1377. [CrossRef] [PubMed]

32. Goldenberg, D.; Mayskiy, M.; Mossey, C.; Ruthazer, R.; Schmid, C. A randomized, double-blind crossover trial of fluoxetine and amitriptyline in the treatment of fibromyalgia. Arthritis Rheum. 1996, 39, 1852-1859. [CrossRef] [PubMed]

33. Hannonen, P.; Malminiemi, K.; Yli-Kerttula, U.; Isomeri, R.; Roponen, P. A randomized, double-blind, placebo-controlled study of moclobemide and amitriptyline in the treatment of fibromyalgia in females without psychiatric disorder. Br. J. Rheumatol. 1998, 37, 1279-1286. [CrossRef] [PubMed]

34. Heymann, R.E.; Helfenstein, M.; Feldman, D. A double-blind, randomized controlled study of amitriptyline, nortriptyline and placebo in patients with fibromyalgia. An analysis of outcome measures. Clin. Exp. Rheumatol. 2001, 19, 697-702. [PubMed]

35. Capaci, K.; Hepguler, S. Comparison of the effects of amitriptyline and paroxetine in the treatment of fibromyalgia syndrome. Pain Clinic 2002, 14, 223-228. [CrossRef]

36. Gulec, H.; Capkin, E.; Sayar, K.; Ak, I. The evaluation of the effectiveness of amitriptyline versus venlafaxine in female patients diagnosed with fibromyalgia syndrome. Klinik Psikofarmakol. Bulteni 2007, 17, 68-73.

37. Konuk, N.; Ortancil, O.; Bostanci, B.; Kiran, S.; Sapmaz, P. A comparison of reboxetine and amitryptilline in the treatment of fibromyalgia syndrome with co-morbid depressive symptoms: An open-label preliminary study. Klinik Psikofarmakol. Bulteni 2010, 20, 29-37. 
38. Calandre, E.P.; Rico-Villademoros, F.; Galan, J.; Molina-Barea, R.; Vilchez, J.S.; Rodriguez-Lopez, C.M.; Hidalgo-Tallon, J.; Morillas-Arques, P. Quetiapine extended-release (Seroquel-XR) versus amitriptyline monotherapy for treating patients with fibromyalgia: A 16-week, randomized, flexible-dose, open-label trial. Psychopharmacology 2014, 231, 2525-2531. [CrossRef] [PubMed]

39. Gur, A.; Karakoc, M.; Nas, K.; Cevik, R.; Sarac, J.; Ataoglu, S. Effects of low power laser and low dose amitriptyline therapy on clinical symptoms and quality of life in fibromyalgia: A single-blind, placebo-controlled trial. Rheumatol. Int. 2002, 22, 188-193. [PubMed]

40. Azad, K.A.; Alam, M.N.; Haq, S.A.; Nahar, S.; Chowdhury, M.A.; Ali, S.M.; Ullah, A.K. Vegetarian diet in the treatment of fibromyalgia. Bangladesh Med. Res. Counc. Bull. 2000, 26, 41-47. [PubMed]

41. Vlainich, R.; Issy, A.M.; Sakata, R.K. Effect of intravenous lidocaine associated with amitriptyline on pain relief and plasma serotonin, norepinephrine, and dopamine concentrations in fibromyalgia. Clin. J. Pain 2011, 27, 285-288. [CrossRef] [PubMed]

42. Anderberg, U.M.; Marteinsdottir, I.; von Knorring, L. Citalopram in patients with fibromyalgia-A randomized, double-blind, placebo-controlled study. Eur. J. Pain 2000, 4, 27-35. [CrossRef] [PubMed]

43. Moldofsky, H.; Harris, H.W.; Archambault, W.T.; Kwong, T.; Lederman, S. Effects of bedtime very low dose cyclobenzaprine on symptoms and sleep physiology in patients with fibromyalgia syndrome: A double-blind randomized placebo-controlled study. J. Rheumatol. 2011, 38, 2653-2663. [CrossRef] [PubMed]

44. Bennett, R.M.; Gatter, R.A.; Campbell, S.M.; Andrews, R.P.; Clark, S.R.; Scarola, J.A. A comparison of cyclobenzaprine and placebo in the management of fibrositis: A double blind controlled study. Arthritis Rheum. 1988, 31, 1535-1542. [CrossRef] [PubMed]

45. Carette, S.; Bell, M.J.; Reynolds, W.J.; Haraoui, B.; McCain, G.A.; Bykerk, V.P. A comparison of amitriptyline, cyclobenzaprine and placebo in the treatment of fibromyalgia: A randomized, double-blind clinical trial. Arthritis Rheum. 1994, 37, 32-40. [CrossRef] [PubMed]

46. Quimby, L.G.; Gratwick, G.M.; Whitney, C.D.; Block, S.R. A randomized trial of cyclobenzaprine for the treatment of fibromyalgia. J. Rheumatol. 1989, 16, 140-143.

47. Reynolds, W.J.; Moldofsky, H.; Saskin, P.; Lue, F.A. The effects of cyclobenzaprine on sleep physiology and symptoms in patients with fibromyalgia. J. Rheumatol. 1991, 19, 452-454.

48. Arnold, L.M.; Lu, Y.; Crofford, L.J.; Wohlreich, M.; Detke, M.J.; Iyengar, S.; Goldstein, D.J. A double-blind, multicenter trial comparing duloxetine with placebo in the treatment of fibromyalgia patients with or without major depressive disorder. Arthritis Rheum. 2004, 50, 2974-2984. [CrossRef] [PubMed]

49. Chappell, A.S.; Bradley, L.A.; Wiltse, C.; Detke, M.J.; D'Souza, D.N.; Spaeth, M. A six-month double-blind, placebo-controlled, randomized clinical trial of duloxetine for the treatment of fibromyalgia. Int. J. Gen. Med. 2008, 30, 91-102. [CrossRef]

50. Arnold, L.M.; Clauw, D.J.; Wohlreich, M.M.; Wang, F.; Ahl, J.; Gaynor, P.J.; Chappell, A.S. Efficacy of duloxetine in patients with fibromyalgia: Pooled analysis of 4 placebo-controlled clinical trials. Prim. Care Companion J. Clin. Psychiatry 2009, 11, 237-244. [CrossRef] [PubMed]

51. Arnold, L.M.; Zhang, S.; Pangallo, B.A. Efficacy and safety of duloxetine $30 \mathrm{mg} / \mathrm{d}$ in patients with fibromyalgia: A randomized, double-blind, placebo-controlled study. Clin. J. Pain 2012, 28, 775-781. [CrossRef] [PubMed]

52. Bradley, L.A.; Bennett, R.; Russell, I.J.; Wohlreich, M.M.; Chappell, A.S.; Wang, F.; D'Souza, D.N.; Moldofsky, H. Effect of duloxetine in patients with fibromyalgia: Tiredness subgroups. Arthritis Res. Ther. 2010, 12, R141. [CrossRef] [PubMed]

53. Murakami, M.; Osada, K.; Mizuno, H.; Ochiai, T.; Alev, L.; Nishioka, K. A randomized, double-blind, placebo-controlled phase III trial of duloxetine in Japanese fibromyalgia patients. Arthritis Res. Ther. 2015, 17, 224. [CrossRef] [PubMed]

54. Russell, I.J.; Mease, P.J.; Smith, T.R.; Kajdasz, D.K.; Wohlreich, M.M.; Detke, M.J.; Walker, D.J.; Chappell, A.S.; Arnold, L.M. Efficacy and safety of duloxetine for treatment of fibromyalgia in patients with or without major depressive disorder: Results from a 6-month, randomized, double-blind, placebo-controlled, fixed-dose trial. Pain 2008, 136, 432-444. [CrossRef] [PubMed]

55. Arnold, L.M.; Wang, F.; Ahl, J.; Gaynor, P.J.; Wohlreich, M.M. Improvement in multiple dimensions of fatigue in patients with fibromyalgia treated with duloxetine: Secondary analysis of a randomized, placebo-controlled trial. Arthritis Res. Ther. 2011, 13, R86. [CrossRef] [PubMed] 
56. Arnold, L.M.; Rosen, A.; Pritchett, Y.L.; D'Souza, D.N.; Goldstein, D.J.; Iyengar, S.; Wernicke, J.F. A randomized, double-blind, placebo-controlled trial of duloxetine in the treatment of women with fibromyalgia with or without major depressive disorder. Pain 2005, 119, 5-15. [CrossRef] [PubMed]

57. Arnold, L.M.; Hirsch, I.; Sanders, P.; Ellis, A.; Hughes, B. Safety and efficacy of esreboxetine in patients with fibromyalgia: A fourteen-week, randomized, double-blind, placebo-controlled, multicenter clinical trial. Arthritis Rheum. 2012, 64, 2387-2397. [CrossRef] [PubMed]

58. Arnold, L.M.; Hess, E.V.; Hudson, J.I.; Welge, J.A.; Berno, S.E.; Keck, P.E. A randomized, placebo-controlled, double-blind, flexible-dose study of fluoxetine in the treatment of women with fibromyalgia. Am. J. Med. 2002, 112, 191-197. [CrossRef]

59. Clauw, D.J.; Mease, P.; Palmer, R.H.; Gendreau, R.M.; Wang, Y. Milnacipran for the treatment of fibromyalgia in adults: A 15-week, multicentre, randomized, double-blind, placebo-controlled, multiple-dose clinical trial. Clin. Ther. 2008, 30, 1988-2004. [CrossRef] [PubMed]

60. Gendreau, R.M.; Thorn, M.D.; Gendreau, J.F.; Kranzler, J.D.; Ribeiro, S.; Gracely, R.H.; Williams, D.A.; Mease, P.J.; McLean, S.A.; Clauw, D.J. Efficacy of milnacipran in patients with fibromyalgia. J. Rheumatol. 2005, 32, 1975-1985. [PubMed]

61. Vitton, O.; Gendreau, M.; Gendreau, J.; Kranzler, J.; Rao, S.G. A double-blind placebo-controlled trial of milnacipran in the treatment of fibromyalgia. Hum. Psychopharmacol. 2004, 19, S27-S35. [CrossRef] [PubMed]

62. Goldenberg, D.L.; Clauw, D.J.; Palmer, R.H.; Mease, P.; Chen, W.; Gendreau, R.M. Durability of therapeutic response to milnacipran treatment for fibromyalgia. Results of a randomized, double-blind, monotherapy 6-month extension study. Pain Med. 2010, 11, 180-194. [CrossRef] [PubMed]

63. Arnold, L.M.; Gendreau, R.M.; Palmer, R.H.; Gendreau, J.F.; Wang, Y. Efficacy and safety of milnacipran $100 \mathrm{mg} /$ day in patients with fibromyalgia: Results of a randomized, double-blind, placebo-controlled trial. Arthritis Rheum. 2010, 62, 2745-2756. [CrossRef] [PubMed]

64. Patkar, A.A.; Masand, P.S.; Krulewicz, S.; Mannelli, P.; Peindl, K.; Beebe, K.L.; Jiang, W. A randomized, controlled, trial of controlled release paroxetine in fibromyalgia. Am. J. Med. 2007, 120, 448-454. [CrossRef] [PubMed]

65. Pae, C.U.; Masand, P.S.; Marks, D.M.; Krulewicz, S.; Peindl, K.; Mannelli, P.; Patkar, A.A. History of depressive and/or anxiety disorders as a predictor of treatment response: A post hoc analysis of a 12-week, randomized, double-blind, placebo-controlled trial of paroxetine controlled release in patients with fibromyalgia. Prog. Neuropsychopharmacol. Biol. Psychiatry 2009, 31, 996-1002. [CrossRef] [PubMed]

66. González-Viejo, M.A.; Avellanet, M.; Hernández-Morcuende, M.I. A comparative study of fibromyalgia treatment: Ultrasonography and physiotherapy versus sertraline treatment. Ann. Readapt. Med. Phys. 2005, 48, 610-615. [CrossRef] [PubMed]

67. TD-9855. Available online: http://www.theravance.com/search?words=fibromyalgia (accessed on 8 March 2017).

68. Morillas-Arques, P.; Rodriguez-Lopez, C.M.; Molina-Barea, R.; Rico-Villademoros, F.; Calandre, E.P. Trazodone for the treatment of fibromyalgia: An open-label, 12-week study. BMC Musculoskelet. Disord. 2010, 11, 204. [CrossRef] [PubMed]

69. Sayar, K.; Aksu, G.; Ak, I.; Tosun, M. Venlafaxine treatment of fibromyalgia. Ann. Pharmacother. 2003, 37, 1561-1565. [CrossRef] [PubMed]

70. Sindrup, S.H.; Otto, M.; Finnerup, N.B.; Jensen, T.S. Antidepressants in the treatment of neuropathic pain. Basic Clin. Pharmacol. Toxicol. 2005, 96, 399-409. [CrossRef] [PubMed]

71. Jasmin, L.; Tien, D.; Weinshenker, D.; Palmiter, R.D.; Green, P.G.; Janni, G.; Ohara, P.T. The NK1 receptor mediates both the hyperalgesia and the resistance to morphine in mice lacking noradrenaline. Proc. Natl. Acad. Sci. USA 2002, 99, 1029-1034. [CrossRef] [PubMed]

72. Sawynok, J. Topical and peripherally acting analgesics. Pharmacol. Rev. 2003, 55, 1-20. [CrossRef] [PubMed]

73. Liu, J.; Reid, A.R.; Sawynok, J. Spinal serotonin 5-HT7 and adenosine A1 receptors, as well as peripheral adenosine A1 receptors, are involved in antinociception by systemically administered amitriptyline. Eur. J. Pharmacol. 2013, 698, 213-219. [CrossRef] [PubMed]

74. Teitelbaum, J.; Johnson, C.; St Cyr, J. The use of D-ribose in chronic fatigue syndrome and fibromyalgia: A pilot study. J. Altern. Complement. Med. 2006, 12, 857-862. [CrossRef] [PubMed]

75. Reynolds, I.J.; Miller, R.J. Tricyclic antidepressants block N-methyl-D-aspartate receptors: Similarities to the action of zinc. Br. J. Pharmacol. 1988, 95, 95-102. [CrossRef] [PubMed] 
76. Cai, Z.; McCaslin, P.P. Amitriptyline, desipramine, cyproheptadine and carbamazepine, in concentrations used therapeutically, reduce kainate- and N-methyl-D-aspartate-induced intracellular $\mathrm{Ca}^{2+}$ levels in neuronal culture. Eur. J. Pharmacol. 1992, 14, 53-57. [CrossRef]

77. Ceko, M.; Bushnell, M.C.; Gracely, R.H. Neurobiology underlying fibromyalgia symptoms. Pain Res. Treat. 2012, 2012, 585419. [CrossRef] [PubMed]

78. Wattiez, A.S.; Libert, F.; Privat, A.M.; Loiodice, S.; Fialip, J.; Eschalier, A.; Courteix, C. Evidence for a differential opioidergic involvement in the analgesic effect of antidepressants: Prediction for efficacy in animal models of neuropathic pain? Br. J. Pharmacol. 2011, 163, 792-803. [CrossRef] [PubMed]

79. Wang, G.K.; Russell, C.; Wang, S.Y. State-dependent block of voltage-gated Na+ channels by amitriptyline via the local anesthetic receptor and its implication for neuropathic pain. Pain 2004, 110, 166-174. [CrossRef] [PubMed]

80. Galeotti, N.; Ghelardini, C.; Bartolini, A. Involvement of potassium channels in amitriptyline and clomipramine analgesia. Neuropharmacology 2001, 40, 75-78. [CrossRef]

81. Tsantoulas, C.; McMahon, S.B. Opening paths to novel analgesics: The role of potassium channels in chronic pain. Trends Neurosci. 2014, 37, 146-158. [CrossRef] [PubMed]

82. Raffa, R.B.; Pergolizzi, J.V., Jr. The evolving understanding of the analgesic mechanism of action of flupirtine. J. Clin. Pharm. Ther. 2012, 37, 4-6. [CrossRef] [PubMed]

83. Wood, P.B.; Schweinhardt, P.; Jaeger, E.; Dagher, A.; Hakyemez, H.; Rabiner, E.A.; Bushnell, M.C.; Chizh, B.A. Fibromyalgia patients show an abnormal dopamine response to pain. Eur. J. Neurosci. 2007, 25, 3576-3582. [CrossRef] [PubMed]

84. Horst, W.D.; Preskorn, S.H. Mechanisms of action and clinical characteristics of three atypical antidepressants: Venlafaxine, nefazodone, bupropion. J. Affect. Disord. 1998, 51, 237-254. [CrossRef]

85. Gummersheimer, A.; Todd, T.; Herndon, C.M. Bupropion use for adjuvant analgesia in a patient with fibromyalgia: A case report. Fibrom. Open Access 2016, 1, 106.

86. Palangio, M.; Flores, J.A.; Joyal, S.V. Treatment of fibromyalgia with sibutramine hydrochloride monohydrate: Comment on the article by Goldenberg et al. Arthritis Rheum. 2002, 46, 2545-2546. [CrossRef] [PubMed]

87. Arnold, L.M.; Gebke, K.B.; Choy, E.H. Fibromyalgia: Management strategies for primary care providers. Int. J. Clin. Pract. 2016, 70, 99-112. [CrossRef] [PubMed]

88. Luciano, J.V.; Forero, C.G.; Cerdà-Lafont, M.; Peñarrubia-María, M.T.; Fernández-Vergel, R.; Cuesta-Vargas, A.I.; Ruíz, J.M.; Rozadilla-Sacanell, A.; Sirvent-Alierta, E.; Santo-Panero, P.; et al. Functional status, quality of life, and costs associated with fibromyalgia subgroups: A latent profile analysis. Clin. J. Pain 2016, 32, 829-840. [CrossRef] [PubMed]

89. Woodcock, J.; Witter, J.; Dionne, R.A. Stimulating the development of mechanism-based, individualized pain therapies. Nat. Rev. Drug Discov. 2007, 6, 703-710. [CrossRef] [PubMed] 